\title{
Selected caries diagnostic methods
}

\author{
Ewa KuChta ${ }^{1}$, Jolanta SzYmansKa ${ }^{2 *}$ \\ ${ }^{1}$ Doctoral student, Medical University of Lublin, Poland \\ ${ }^{2}$ Research supervisor, Chair and Department of Paedodontics, Medical University of Lublin, Poland
}

\begin{tabular}{l} 
ARTICLE INFO \\
\hline Received 24 October 2014 \\
Accepted 26 November 2014 \\
\hline
\end{tabular}

\section{Keywords:}

dental caries,

caries detection,

diagnostic methods.

\begin{abstract}
Standard caries diagnostic methods include a visual tactile method, as well as several radiographic methods. The former is a subjective method, while bitewing radiographs and digital radiographs (radiovisiography) enable detection of caries lesions only after $30 \%$ of hard dental tissue mineral substances have been lost. The paper presents methods based on electrical and optical phenomena that allow early caries diagnosis. Strengths and weaknesses of each presented method are discussed, basing this on recent literature review. The methods of caries detection generally used in daily clinical practice, combined with alternative methods, make it possible to significantly increase the effectiveness of dental caries diagnosis.
\end{abstract}

\section{INTRODUCTION}

Maintaining one's own teeth is an important factor that affects both the normal chewing function and the quality of chewing, and early caries detection enables earlier treatment with tooth tissue-saving therapeutic methods. Early caries diagnosis is particularly important at the developmental age. At this stage of life, caries development is usually increased, while its consequences may be extensive, including the need for endodontic treatment and malocclusion. An additional consequence is decreased self-esteem (in both children and adolescents). The complex structure of occlusal surfaces, as well as deep and difficult to clean fissures, are conducive to caries development, especially on the chewing surface of teeth. This, at its early stage, is practically undetectable with conventional diagnostic methods. In addition, as a result of greater pro-health dental awareness and dental hygiene in adults, one can observe an increase in the frequency of incipient, arrested and secondary caries which are also difficult to diagnose. It should also be observed that although visual diagnostic examination completed with radiography increases the probability of caries lesions detection, it does not allow the diagnosing of the earliest lesions. Thus, the possibility of using alternative dental caries diagnostic methods is a great advantage $[6,7,15,16,20,26]$.

Corresponding author

e-mail: szymanska.lublin@gmail.com

\section{The visual tactile method}

The visual tactile method of caries detection is one of the methods most commonly used by dentists. It is a visual assessment in artificial light of the cleaned and dried teeth surfaces, and it does not require additional specialist devices. The instruments used in this type of examinations are: dental mirrors, dental unit air syringes and probes. The use of the traditional probe has recently been discouraged because of the risk of mechanically damaging the enamel with the sharp end of the tool, as well as inoculating pits and fissures with oral bacteria. Beyond the aforementioned, to increase diagnostic effectiveness, devices to broaden the visual field are used, e.g., the magnifying loupe or intraoral camera, and in the case of tangent surfaces - appropriate orthodontic separators. It follows from the literature that the specificity of the visualtactile method reaches ca. $90 \%$, while its sensitivity varies from $12-82 \%[2,6,11,13,15,16,20]$.

\section{Radiological methods}

Radiological examination (bitewing radiographs) and digital radiographs (radiovisiography) are commonly used to detect dental caries. In a radiograph, the signs of caries being present are irregular and clearly defined spots of increased opacity in the area of hard tooth tissue - this concerns both teeth crowns and roots. Of note, demineralized tissues are more radiolucent than normal ones, and produce darkened spots on the film.

a) Bitewing radiographs. Bitewing radiographs are used in caries diagnosis of the distal surface of incisors, the tangent and occlusal surfaces of lateral teeth, and in 
hidden caries detection - making such surfaces more clearly visible. However, caries lesions become evident only after a loss of a minimum of $30 \%$ of the tooth mineral substances. It is, therefore, impossible to detect very early caries lesions in the enamel. What is more, the interpretation of lesions on tangent surfaces is difficult in the case of tooth crowding [2,6,9,14-17,19,20,25].

b) Digital radiographs (radiovisiography).The equipment of many dental surgeries includes devices for taking digital radiographs (radiovisiography). In this method, the dose of ionizing radiation is decidedly smaller than in classic radiography (including bitewing radiographs). In addition, computer image processing may be performed to increase the visibility of the diagnosed structures. It is also possible to process, transfer and record the digital image. However, it should be noted that tangent surfaces of teeth are less visible in digital radiographs that in correctly taken classic bitewing radiographs $[2,20]$.

\section{Methods based on electrical and optical phenomena}

a) Method based on a difference in tooth tissue electric resistance. Electronic Caries Monitor (ECM) is a diagnostic method based on a difference in tooth tissue electric resistance. The method enables detection of incipient caries lesions reaching the dentine-enamel junction. Normal enamel and dentine are characterized by having high electric resistance, while in the case of caries lesions, electric resistance decreases. The method shows high specificity and sensitivity, but it is not commonly used $[2,19,20]$.

b) Transillumination method. The Fiberoptic Transillumination method (FOTI), based on an optical phenomenon, is used to detect caries in tangent surfaces of teeth. The approach consists of illuminating such surfaces with high-intensity light. The presence of caries lesions causes light dispersion, which is visible as a shadow surrounded by brighter, healthy tissues. In utilising the method, highintensity light (2000 lux) is transmitted through thin fiberoptic cables. A newer version of this method enables digital image processing with suitable software (DIFOTI). The approach is characterized by high sensitivity and specificity $[2,14,19,20]$.

c) Fluorescence methods. In the qualitative light-induced fluorescence method, $370 \mathrm{~nm}$ black light emitted by a halogen lamp is used. Tooth tissues exposed to this light produce a fluorescence that is recorded and processed by a computer. This device is not commonly used in clinical practice, but often applied in scientific research $[2,9,12$, 15,16,19-21].

Laser Fluorescence (LF) is used to diagnose occlusal caries with the DIAGNOdent device (KaVo), where the source of light is a laser diode emitting $655 \mathrm{~nm}$ light. The phenomenon of fluorescence consists in light energy emission by tooth tissues molecules due to their excitation by laser light. The laser light is absorbed by porphyrines, i.e. caries bacteria metabolites. Caries lesions show greater fluorescence than healthy tissues, which is signalled by the DIAGNOdent sound signal and a number displayed on the device's monitor. Tooth tissue fluorescence is processed into a 0-99 scale. The more intense the caries lesions, the greater number the devices shows. According to the criteria used in examination with DIAGNOdent by Lussi et al. and the DIGNOdent score recommended by the manufacturer, a normal tooth scores from 0-14, enamel caries score: 15-20, while a result over 21 points to dental caries and is an indication for treatment intervention [2,5-7,9,10,15-20,22,24-26]. In the case of dental plaque presence, non-caries tooth discoloration or polishing paste remains, there is a risk of false positive result. Therefore, it is recommended that the tooth surfaces be cleaned and dried carefully before using DIAGNOdent $[20,26]$. The sensitivity and specificity of caries diagnosis with DIAGNOdent are assessed as high, and the device enables a noninvasive and painless detection of early caries lesions in tooth tissues. An examination with this device is also well tolerated by the youngest patients, and it is recommended in caries diagnosis in pregnant women who must not be exposed to ionizing radiation. DIAGNOdent allows an objective assessment of tooth hard tissues, results repeatability and the monitoring of the progress of caries lesions in time. Furthermore, neither patients nor dental staff are exposed to radiation, as it is the case during bitewing radiography or radiovisiography.

Of interest is that, as diagnosing caries of teeth tangent surfaces is a difficult clinical problem, a device that may be used in such diagnosis is the DIAGNOdent pen $(\mathrm{KaVo})$. This has a wedge-shaped tip that facilitates the examination of mesial and distal surfaces. The principle of its operation is the same as that in the utilizing the normal DIAGNOdent (KaVo) device. The pen is easy to handle, and in some situations, may be an alternative to bitewing radiographs that does not expose patients to $\mathrm{X}$-radiation $[2,6,14,18,22,24]$. It should be stressed that the normal DIAGNOdent device and the DIAGNOdent pen are popular and are commonly used in everyday clinical practice.

The most recent device launched by KaVo is DIAGNOcam. It is a camera that allows caries diagnosis using $780 \mathrm{~nm}$ laser light, which, passing through tooth tissues, produces an image similar to a radiograph. Carious tissues disturb the passage of light and are visible as dark regions in the obtained image. The device may be used to diagnose occlusal, smooth, and tangent surfaces, secondary caries and enamel breaks. With this device, the presence of dental plaque does not lead to false positive results. In addition, images obtained with DIAGNOdent can be shown to the patient on a computer screen.

d) Method based on the phenomenon of changes in light polarization. Polarization Sensitive Optical Coherence Tomography (PS-OCT) is based on the phenomenon of changes in light polarization when in contact with tooth tissues. In demineralized enamel, light diffusion is increased and the degree of light depolarization changes. As a result, a coloured or grey, two- or three dimensional image is obtained. This makes it possible to detect early caries, to determine demineralization degree and to monitor its changes in time $[8,23]$. 
Table 1. Methods of caries diagnosis

\begin{tabular}{|c|c|c|c|c|}
\hline Type of examination & Principles of operation & Advantages & Disadvantages & References \\
\hline Visual tactile method & $\begin{array}{l}\text { Visual examination of a dried and } \\
\text { illuminated tooth surface; possibly } \\
\text { enhanced by the use of magnifying } \\
\text { tools/devices. }\end{array}$ & $\begin{array}{l}\text { Easy, painless method. } \\
\text { Does not require the use of } \\
\text { expensive devices. } \\
\text { Safe for pregnant women and } \\
\text { children. }\end{array}$ & $\begin{array}{l}\text { Subjective method. } \\
\text { Impossible to detect early } \\
\text { changes on tangent and } \\
\text { occlusal surfaces. }\end{array}$ & {$[2,6,11,13,15,16,20]$} \\
\hline Radiological methods & $\begin{array}{l}\text { Bitewing radiographs - images } \\
\text { showing several teeth of the upper } \\
\text { and lower arch; occlusal and } \\
\text { tangent surfaces visible. } \\
\text { RVG - digital X-ray image } \\
\text { (radiovisiography) - image } \\
\text { obtained on a computer screen. }\end{array}$ & $\begin{array}{l}\text { High precision of occlusal and } \\
\text { tangent surfaces imaging. } \\
\text { High sensitivity of carious } \\
\text { lesions detection. } \\
\text { Smaller dose of ionizing } \\
\text { radiation compared to } \\
\text { conventional imaging. } \\
\text { Possibility of digital processing, } \\
\text { recording and transfer } \\
\text { (consultations) }\end{array}$ & $\begin{array}{l}\text { Detection of carious lesions } \\
\text { only at } 30 \% \text { loss of mineral } \\
\text { substances in tooth tissues. } \\
\text { Necessity to use special film. } \\
\text { Higher doses of ionizing } \\
\text { radiation. } \\
\text { Contraindicated in pregnant } \\
\text { women and young children. } \\
\text { Detection of carious lesions } \\
\text { only at } 30 \% \text { loss of mineral } \\
\text { substances in tooth tissues. } \\
\text { A special camera and } \\
\text { photocamera and computers } \\
\text { are necessary. } \\
\text { Contraindicated in pregnant } \\
\text { women and young children. }\end{array}$ & $\begin{array}{c}{[2,6,9,14,15,17,19,} \\
20,24]\end{array}$ \\
\hline $\begin{array}{l}\text { ECM (electronic caries } \\
\text { monitor) }\end{array}$ & $\begin{array}{l}\text { Based on the difference in electric } \\
\text { resistance between healthy and } \\
\text { carious tooth tissues. } \\
\text { Carious lesions show decreased } \\
\text { electric resistance. }\end{array}$ & $\begin{array}{l}\text { High sensitivity and specificity. } \\
\text { Makes early caries detection } \\
\text { possible }\end{array}$ & A special device is necessary. & {$[2,19,20]$} \\
\hline Transillumination & $\begin{array}{l}\text { FOTI consists in illumination } \\
\text { of tangent surfaces with high- } \\
\text { intensity light. Caries visible as } \\
\text { shadow. } \\
\text { DIFOTI - the obtained image is } \\
\text { processed by a special computer } \\
\text { programme and shown on a } \\
\text { computer screen. }\end{array}$ & $\begin{array}{l}\text { High sensitivity and specificity. } \\
\text { Simple, noninvasive and } \\
\text { painless method. } \\
\text { Can be used in pregnant women } \\
\text { and young children }\end{array}$ & Special equipment necessary. & {$[2,14,19,20]$} \\
\hline Fluorescence & $\begin{array}{l}\text { QLF - a method based on } \\
\text { qualitative fluorescence induced } \\
\text { with light. Tooth tissues exposed } \\
\text { to } 370 \mathrm{~nm} \text { light of a halogen lamp } \\
\text { emit fluorescence that is recorded } \\
\text { and processed to a computer } \\
\text { image. } \\
\text { LF - laser fluorescence method } \\
\text { (devices: DIAGNOdent, } \\
\text { DIAGNOdent pen). } \\
\text { Light source - laser diode emitting } \\
655 \text { nm light. } \\
\text { Stimulation of tooth hard tissues } \\
\text { with light causes excitation of } \\
\text { molecules constituting tooth } \\
\text { tissues and emission of light } \\
\text { recorded by the device. Carious } \\
\text { tissues show higher fluorescence } \\
\text { that healthy ones, which is } \\
\text { signalled with a sound and a } \\
\text { number displayed on the device } \\
\text { monitor. }\end{array}$ & $\begin{array}{l}\text { High sensitivity and specificity in } \\
\text { enamel lesions diagnosis. } \\
\text { Makes early caries detection } \\
\text { possible. } \\
\text { Easy, noninvasive and painless } \\
\text { examination. } \\
\text { Easy, quick and painless } \\
\text { method. } \\
\text { Detects early caries on smooth, } \\
\text { occlusal and tangent surfaces } \\
\text { (DIAGNOdent pen). } \\
\text { Well tolerated by young } \\
\text { children. } \\
\text { Safe for pregnant women and } \\
\text { children. } \\
\text { Results repeatable. } \\
\text { Makes monitoring of lesions } \\
\text { progress in time possible. }\end{array}$ & $\begin{array}{l}\text { Special equipment } \\
\text { necessary. } \\
\text { Does not detect lesions in } \\
\text { dentine. } \\
\text { Does not detect lesions } \\
\text { under restorations. }\end{array}$ & $\begin{array}{c}{[2,9,12,15,16,19-21]} \\
{[2,5-7,9,10,15-20,} \\
22,24-26]\end{array}$ \\
\hline $\begin{array}{l}\text { Polarization sensitive optical } \\
\text { coherence tomography } \\
(\mathrm{PS}-\mathrm{OCT})\end{array}$ & $\begin{array}{l}\text { Uses white polarized light - } \\
\text { superluminescent diode (SLD). } \\
\text { Enables determination of the } \\
\text { degree of enamel demineralization. } \\
\text { After detection and computer } \\
\text { analysis, 2D or even 3D images } \\
\text { can be obtained. }\end{array}$ & $\begin{array}{l}\text { Painless, harmless to patients, } \\
\text { highly effective. }\end{array}$ & & {$[8,23]$} \\
\hline Impedance spectroscopy & $\begin{array}{l}\text { Assessment of mineral density of } \\
\text { tooth hard tissues. }\end{array}$ & $\begin{array}{l}\text { High specificity and sensitivity. } \\
\text { Device easy to handle. Quick } \\
\text { examination, exact and } \\
\text { repeatable measurements. }\end{array}$ & & {$[3,4]$} \\
\hline $\begin{array}{l}\text { Energy conversion } \\
\text { technology }\end{array}$ & $\begin{array}{l}\text { Enables assessment of tooth } \\
\text { tissues crystal structure using } \\
\text { photothermal radiometry and } \\
\text { luminescence (The Canary System). }\end{array}$ & $\begin{array}{l}\text { Detection of secondary caries } \\
\text { early foci. }\end{array}$ & & [1] \\
\hline
\end{tabular}

e) Method based on the impedance spectroscopy. Alternating Current (AC) Impedance spectroscopy has been harnessed for use by way of the CarieScan PROTM device. The electronic measurement of tooth hard tissue impedance is based on enamel physical properties, i.e., the mineral density of the examined tooth hard tissues, and is characterized by high specificity and sensitivity. The device is easy to handle, enables a quick, painless examination and guarantees exact and repeatable measurements $[3,4]$. f) The Canary System - method based on the energy conversion technology. The detection of secondary caries foci found around or under a restoration is an important clinical problem. In the Canary System, the energy conversion technology has been used. Pulses of laser light aimed at tooth tissues are converted to heat and light, while an algorithm that combines the results of photothermal radiometry and luminescence allows assessment of the status of the enamel or root surface crystal structure [1]. 


\section{CONCLUSION}

In summary, it should be stated that routine caries diagnostic methods used in clinical practice completed with alternative methods, enable a marked increase in the effectiveness of dental caries diagnosis. Combining several methods is particularly important in early caries diagnosis in patients at the developmental age, on tangent surfaces, and in the case of hidden and secondary caries.

\section{REFERENCES}

1. Abrams S.H.: Detecting caries at the margin of restorations with the Canary System. Dental Tribune, 6, 14, 2012.

2. Braga M.M., Mendes F.M., Ekstrand K.R.: Detection activity assessment and diagnosis of dental caries lesions. Dent. Clin. N. Am., 54: 479, 2010.

3. Chałas R. et al.: AC-impedance spectroscopy and caries detection. Curr. Issues Pharm. Med. Sci., 26, 344, 2013.

4. Chałas R. et al.: Usefulness of AC-impedance spectroscopy technique in occlusal caries detection - own investigations. Curr. Issues Pharm. Med. Sci., 26, 440, 2013.

5. Chu C.H., Lo E.C.M., You D.S.: Clinical diagnosis of fissure caries with conventional and laserinduced fluorescence techniques. Laser Med. Sci., 25, 355, 2010.

6. Costa A.M., Paula L.M., Bezerra A.C.B.: Use of DIAGNOdent for diagnosis of non-cavitated occlusal dentin caries. J. Appl. Oral Sci., $16,18,2008$.

7. Diniz M.B. et al.: The efficacy of laser fluorescence to detect in vitro demineralization and remineralization of smooth enamel surfaces. Photomed. Laser. Surg., 27, 1, 2009.

8. Drabarczyk M., Kacprzak M., Mielczarek M.: Nowa metoda diagnostyczna w stomatologii - tomografia optyczna. Stomatol. Współcz., 7, 34, 2000.

9. Gutknecht N. et al.: Lasers in pediatric dentistry - a review. J. Oral Laser Appl., 5, 207, 2005.

10. Kouchaji C.: Comparison between a laser fluorescence device and visual examination in the detection of occlusal caries in children. Saudi Dent. J., 24, 169, 2012.

11. Kühnisch J. et al.: Development, methodology and potential of the new Universal Visual Scoring System (UniViSS) for caries detection and diagnosis. Int. J. Environ. Res. Public Health., 6, 2500, 2009.

12. Mielczarek A. et al.: Ocena porównawcza wykorzystania fluorescencji różnicowej i systemu ICDAS II w diagnostyce próchnicy badania in vitro. Nowa Stomatol., 4, 103, 2009.
13. Mielczarek A., Kwiatkowska A.: Aktualne koncepcje diagnostyki próchnicy. Stomatol. Wpółcz., 12, 11, 2005.

14. Mirska-Miętek M.: Diagnozowanie zmian próchnicowych na powierzchniach stycznych zębów stałych. Ann. Acad. Med. Stetin.,56, 70, 2010.

15. Nokhbatolfoghahaie H. et al.: Evaluation of accuracy of DIAGNOdent in diagnosis of primary and secondary caries in comparison to conventional methods. J. Laser. Med. Sci., 4, 159, 2013.

16. Oancea R. et al.: In vitro evaluation of laser fluorescence devices for caries detection through stereomicroscopic imaging. Rom. J. Morphol. Embryol., 54, 333, 2013.

17. Pinheiro I.V.A. et al.: Use of laser fluorescence (DIAGNOdent) for in vivo diagnosis of occlusal caries: a systematic review. J. Appl. Oral Sci., 12, 177, 2004.

18. Ranga R.: Performance of a new fluorescence diagnostic device in early carious lesion detection. OHDMBSC., 6, 21, 2007.

19. Rechmann P. et al.: Performance of laser fluorescence devices and visual examination for the detection of occlusal caries in permanent molars. J. Biomed. Opt., March 2012; 17 (3). (PDF 3,6 MB ). 2012 Mar;17(3):036006. doi: 10.1117/1.JBO.17.3.036006. http://http:// biomedicaloptics.spiedigitallibrary.org/article.aspx?articleid=1183 075\&resultClick=1. 09.08.2014.

20. Rodakowska E., Waszkiel D.: Ocena porównawcza wzrokiem oraz za pomocą aparatu Diagnodent występowania próchnicy pierwszych zębów trzonowych. J. Stomatol., 64, 385, 2011.

21. Shamsa S. et al.: Porównanie skuteczności wybranych metod diagnostycznych w wykrywaniu i ocenie stopnia zaawansowania wczesnych zmian próchnicowych na powierzchniach żujących pierwszych zębów trzonowych stałych u dzieci. Nowa Stomatol., 2, 61, 2013.

22. Sridhar N., Tandon S., Rao N.: A comparative evaluation of DIAGNOdent with visual and radiography for detection of occlusal caries: an in vitro study. Indian J. Dent. Res., 20, 326, 2009.

23. Tanasiewicz Marta. Próchnica zębów. Wybrane problemy diagnostyki, leczenia i zapobiegania. Wydawnictwo Elamed, Katowice, 2009.

24. Virajsilp V. et al.: Comparison of proximal caries detection in primary teeth between laser fluorescence and bitewing radiography. Pediatr. Dent., 27, 493, 2005.

25. Wędrychowicz-Welman A., Prymas A., Lewandowski P.: Diagnostyka próchnicy powierzchni żujących zębów bocznych metodą fluorescencji laserowej. Dent. Med. Probl., 44, 207, 2007.

26. Woźniak J. et al.: Powtarzalność pomiarów fluorescencji za pomocą aparatu Diagnodent na powierzchniach żujących zębów trzonowych w warunkach in vitro. Dent. Med. Probl., 45, 255, 2008. 